\title{
COMMON AFFAIR OF POLITICS AND EDUCATION: DEMOCRACY, CIVIL SOCIETY, PERSONALITY
}

\author{
Mykola Lipin \\ Doctor of Sciences in Philosophy, Associate Professor, \\ Kyiv National University of Trade and Economics, Ukraine \\ e-mail: m.lipin@knute.edu.ua, orcid.org/0000-0003-0940-088X
}

Nataliia Husieva

Ph.D., Associate Professor, Kyiv National University of Trade and Economics, Ukraine e-mail: n.gusieva@knute.edu.ua,orcid.org/0000-0002-6062-6406

\begin{abstract}
Summary
This article consideres the problem of the correlation of the politics and education. The scientific approaches to understanding the upbringing and teaching as one of the important spheres of the state politics are analyse. In the borderlines of this scientific approaches the education becomes the service instrument of the satisfaction of the outside education interests. Opposite approach according to which the regime of politics substantially is differs from the regime of police by it's attitude to power is simultaneously motivated. Politics can exist in the form of participation of citizens in the common affair, as democracy, as an uninterrupted debate concerning common affair. However democracy means the appropriate level of enlightenment and education of the mass. Thus regime of the politics can exist only supported by education. The essence of the education as a common affair is realized in the conditions of the democratic equality. Not only politics can exist supported by education, but the education corresponds to the logic of human development.
\end{abstract}

Keywords: Education, culture, politics, ideology, democracy, state.

DOI: https://doi.org/10.23856/4423

\section{Introduction}

According to the literature devoted to the problems of education, there is a specific mainstream, according to which politics and education are presented as two opposite, not having an internal interrelation of the sphere of public life. Their external connection is allowed in a strictly hierarchical form: either education is subordinated to politics, or politics must be subordinated to education. The first option more often dominates when describing the current situation in society; the second one exists with the institution of the proper public order.

However, in everyday life we most often come across the option of subordinating education to politics. The subordination of education to politics does not necessarily have a conscious, purposeful character. In this regard, the concepts that are common in our time, relating knowledge and power, ideology and education, are illustrative. In these approaches, education becomes the sphere of embodiment of government practices. In other words, it appears to be one of the "authorities of power", one of the "pure" incarnations of the desire of the state or society to educate the rights of citizens and it is one of the effective ways of legitimizing the existing social order. This state of affairs suggests that, firstly, politics is identified with the struggle for power, and secondly, that the purpose of the institution of education is basically limited to the fulfillment of the "social order" of power. 
Purpose of the article is to investigate the relationship between education and politics in the process of realizing the common cause peculiar to both of them such as the formation of the human community.

\section{The analysis of recent research and publications}

The problem of the correlation of politics, power and education is presented in many studies. Among them, M. Foucault's works are important, in which the interrelation between the education and the formation of disciplinary authority is examined. "Any education system is a political way of maintaining or changing the forms of appropriating discourses with all the knowledge and forces that they entail," he wrote on this matter (Foucault M., 1998: 74).

Such point of view has been existed since the time of K. Marks in studies devoted to the influence of ideology on the process of the formation of public consciousness, so it is not surprising that the followers of his ideas developed this theme. For example, from the point of L. Althusser's view, the school appears as an institution for the reproduction of the labor force in accordance with the existing structure of the division of labor. It follows that the school is the place for formation of professional qualifications and reproduction of subordination of the individual to the rules of the established order. "That is, the reproduction of the subordination of the dominant ideology of the workers and the reproduction of the ability to correctly manipulate the dominant ideology of the exploiters, so that they and" in words "also ensure the domination of the ruling class" (Althusser L., 2011: 23).

Proceeding from these pre-conditions, P. Bourdieu (a student of L. Althusser), along with J.-C. Passeron developed their own concept of the "sociology of education". In their joint study "Reproduction: elements of the Theory of the Education System," they revealed the specifics of the relationship between the education system and the system of class relations. From their point of view, the "democratization" of social relations gradually leads to the fact that the government ceases to rely on the mechanisms of physical coercion and begins to widely use "symbolic violence" (Bourdieu P., Passeron J.-Cl., 2007: 19).

P. Bourdieu and J.-C. Passeron also believed that the transformation of social conditions leads to "that the transfer of power and privileges now, more than in any other society, must be bypassed through recognition by the educational system. Social conditions do not allow pedagogical violence to openly manifest its truth of social violence" (Bourdieu P., Passeron J.-Cl., 2007: 19).

In another work "The Education System and the System of Thinking" of P. Bourdieu, the education was defined as a way of "ordering the dominant hierarchies and classifications", and the school as "the queen of classifications and classroom" (Bourdieu P., 1997: 119). Despite the fact that the education system is interpreted by most modern researchers as a way of imposing ideological ideas about the world and the place of a person in it, it can simultaneously serve as a basis for overcoming ideological dictates. The fact is that with the help of education a person gets the opportunity to make the object of his attention as the foundations of his activity and thinking (Bourdieu P., 1997: 119).

Important for our research is H. Arendt's work "The Crisis in Education" in which she criticizes the interpretation "education became an instrument of politics, and political activity itself was conceived of as a form of education" (Arendt H., 1961: 185). The difference between politics and education is that the first is the sphere of interaction between equals, and the second is the interaction of adults with children, which is initially understood by H. Arendt as "authoritarian". Such a shift of politics beyond the boundaries of education may paradoxically 
contribute to the market colonization of education and the accompanying "politics of depoliticization" (Szkudlarek T., 2013: 1).

Despite a long tradition of juxtaposing education and politics, "the connection between educational and political theories seems still to be underestimated" (Szkudlarek T., 2013: 1). Education cannot be just a preparation for adult life, which is associated with politics. If democracy, the principles of civil society are not present in the school life of children, then one should not expect that they will be present in their life after school (Biesta G., 2014: 101).

\section{Heterotopy of education}

There are two options for interpreting the existence of a politics in education. One of them directly notes the importance and legitimacy of the presence of politics in education as its main determinant. Politics is the driving force behind education. The state (the possibility of the existence of politics in this case is identified with the state) uses the education system to justify its existence. It should be mentioned that even Aristotle's question about education and its goals is directly related to the welfare of the state (Aristotle, 1983: 628).

As the consequence the long tradition of interpreting education in the context of the process of legitimizing the existing regime of power appeared. Illustrative examples of such an instrumental attitude to the education system can be found in the texts of numerous utopias and anti-utopias, which for the most part give education one of the leading roles in building an "ideal" society. In this situation, the educational system is assigned the role of a conductor of the idea of power. Any anti-utopia can't exist without a description of the education system, which is designed to serve as an effective tool for influencing the human consciousness, its production in accordance with the needs of the existing order. However, not only the ideal, but also the real state seeks to educate and form the person as it needs. The example of anti-utopias represents a variant of the explicit use of education for the purposes of political power, when "symbolic violence" is reinforced by all other types of violence and is provided by them. Here the political authorities often do not even try to hide their violent nature.

At the same time, the indicated option of using education for purposes of politics implies the possibility of opposing the influence of power. "There is power so there is opposition" (Foucault M., 1996: 195). Even in totalitarian societies, education managed to find ways to avoid practices prescribed by politics and was never completely exhausted by them.

The point is that education, in order to remain itself, must be rooted in a culture that opens the possibility of forming immunity against the viruses of power. In turn, the lack of immanent cultural resistance to the actuality of the present indicates a kind of immunodeficiency of culture (Pakhlovska O., 2003: 83).

In this perspective, we are dealing with the ability of education (more broadly than culture) to constitute "other spaces" of social interrelations, which can be defined as heterotopies or realized utopia according to M. Foucault's words (Foucault M., 2006: 197). Heterotopies of education are constituted outside of total determination by political power.

At one time, P. Bourdieu defined politics precisely as a struggle for "imposing a legitimate principle of vision and division, dominant and recognized as deserving of this, that is, full of symbolic violence" (Bourdieu P., Kachanov Yu., Pento L., Shmatko N., 2001: 125-126). According to this point of view, the institution of education is characterized by the practice of "symbolic violence", in which the interrelation between politics and education is revealed. So, politics, which appears nothing more than a struggle for power, allows education in the form of 
one of the effective ways of producing ideological ideas of the individual about the world and its place in it.

On the example of the functioning of ideology, the mechanisms of "symbolic violence" one can observe the implicit, hidden use of education for the purposes of political struggle. Subjects of the pedagogical process reproduce the dominant ideas, often not realizing their ideological bias, partiality and abstractness. In this case, the apology of the existing social order unfolds not as the execution of an explicit order of power, but as a "natural" process of transferring information from one generation to another. However, this relationship between politics and education substantially distorts their real nature.

\section{Politics, symbolic order and democracy}

The traditional understanding of politics as a struggle for power is contested in the framework of J. Ranciere's theory. From his point of view, the situation described does not correspond to politics, but to the police. In other words, not everything that revolves around power is politics. And even more than that, what revolves around power is not politics. "Politics is not the exercise of power. We immediately omit and jump over it, if we identify it with the practice of power and with the struggle for its possession," the researcher wrote (Ranciere J., 2006: 195). Consequently, the power is the point of attraction of the police, an order in which it is impossible to separate the sensory among all participants in the process, it is impossible to dispute the general.

Politics, understood as a struggle for power, tends to slip into the practice of management with the help of technical means created by the order. It assumes the existence of a common as some kind of predetermined, natural entity. Within these boundaries, politics does not appear to be a project that needs to be jointly implemented and then maintained, but as a fact already completed. Therefore, "symbolic violence" is conditioned by the desire to protect such an established order in which a certain group of people occupies a position appropriate to their interests and needs. Hence it turns out that the one who seizes state power is no longer interested in the existence of a political regime, the regime of a dispute over a common one, he seeks to replace politics with a management regime, and a dispute around the common with consensus. But, as J. Ranciere writes, "politics is not the art of governing communities, it is a form of human action based on disagreement, an exception to the rules according to which the rallying of human groups and the management of them" (Ranciere J., 2006: 13).

In the history of social and political thought, the place of the common often becomes the state. In the historical perspective, it seeks to speak on behalf of the common, to be the personification of a common cause. In view of this, the state quite often appears to be a source of politics and, accordingly, a source of production of the "social order" for education. But in connection with the above, it is obvious that the state appears more a source of a uniform order, or, in other words, an abstract general, whose idealization turns out to be disastrous for politics. It, as a place of legal physical and "symbolic violence", it turns politics into the police regime. The strengthening of the state can be accompanied by a growing unity of society, which paradoxically leads to the cutting off the common cause, to its abstractness and formality. "Strengthening of the state in practice turns into a trend that can be designated as an increasingly popular notion of depoliticization," V. Kurennoy wrote (Kurennoy V., 2008: 86).

The essential characteristic of the process of depoliticization is the degradation of public space, i.e. such a space of human relations in which a person can be seen and heard as a sovereign individual. Public space is always constituted as though for the first time, and therefore, 
it is not discourse (language of power) that is being developed within it, but parrhesia (free speech). If the order of the general already takes place, someone necessarily remains beyond its borders; someone is excluded from it, and therefore he remains invisible and unheard. His needs and interests do not exist. But in such conditions, the political process of participation in the creation of a common and not merely an adaptation to its available state forms ceases. In such a situation, both politics and democracy become impossible.

One should pay attention to the fact that the police regime borders on desymbolisation, so that the human community in this optics is exhausted by its existing existence, and hence human development in it is limited by the prevailing principles of empirical existence, which are not questioned. Within the framework of such an order, there are possible ways of implementing policies that are mutually exclusive such as consensus or antagonism.

Ch. Mouffe suggests his own solution to this problem. From her point of view, democratic politics does not exclude conflict, but it transforms antagonism into an agonistic form, which is the "we-they" relationship, in which the conflicting parties recognize each other's legitimacy. "They are "opponents", but not enemies. This means that despite their participation in the conflict, the parties consider themselves to belong to a single symbolic space within which a conflict is taking place. One can say that the task of democracy is to transform antagonism into agonistic form" (Pantin I., 2008: 98).

Democracy is a system of institutionalized struggle for power. Without competition and conflict there will be no democracy. However, any society sanctioning the conflict risks in the end to come to the fact that this conflict becomes too intense to create a society that is so permeated with antagonisms and that civil peace and stability are compromised (Mouffe Ch., 2005: 30-32). In order to find a consensus solution to this problem, a single symbolic space is needed. So, outside the "single symbolic space", politics as a democratic process becomes problematic. Hence the constituting of symbolic space appears decisive for the development of democracy. Outside this space the conflict develops into antagonism. From our point of view, education is the common thing in which a single symbolic space is built.

Politics, unlike the police, assumes not just a common one, in which every single one drowns, dissolves. It assumes such a general, which is the unity of diversity, such a unity in which the singular becomes special. Such concrete-general (as universal) is impossible beyond the conflict of unitary positions that contradict each other. They are not a sign of the depravity of a concrete general, but a prerequisite for its existence. After all, a single symbolic space cannot be empty, abstract universality, which is superimposed superficially on the individual, so forcing it. Otherwise, we are not dealing with a common symbolic space, but with symbolic violence.

\section{Education as a political cause}

A single symbolic space is recreated every time anew in the circulation of one person to another, one generation to another generation. In this appeal the human community is created and existed. Thus, we with necessity, reflecting on politics, turn to thinking about the cultural ways of constituting the human community. It is obvious that education has always played and continues to play a crucial role in this process. And education is understood as a common cause, rather than an area that is exclusively within the jurisdiction of a limited number of professionals.

It should be emphasized that if there is no truly common cause, the measure of the presence of symbolic violence increases. Politics is constituted as a public sphere, as a space where 
a person can be seen and heard. Besides, this space gives a person the opportunity to see in oneself another, to perceive oneself as another. The common cause refers to the ancient tradition of coexistence in the "res publica" mode. "In the classical republican tradition originated from Aristotle and Cicero through Machiavelli, Montesquieu and Tocqueville to such theorists of the twentieth century as Hannah Arendt or Charles Taylor, the term res publica means such a common cause for which it stands live and even lay down his head. The Republic in their understanding is more than a form of government; this is a certain state of the people, supported by the constant participation of citizens in solving issues of general importance," O. Kharkhordin writes (Kharkhordin O., 2009: 15). According to this tradition, the politics creating the prerequisites of a common cause can be a democracy that relies on enlightenment.

In this context, it will be useful to turn to an understanding of democracy in the works of L. Strauss who believed that the question of education is a political issue par excellence, since it allows to solve the problem of "how to reconcile an order that does not oppress, with freedom that is not abused" (Strauss L., 2012: 25). The solution to this problem becomes possible if democracy is understood as a community of educated people. "Democracy is a political order in which all or most adults are virtues, and since virtue seems to require wisdom, it is a regime in which all adults, or most of them, are virtuous and wise, or a regime in which all or most adults developed their minds to a high degree, or rational society. By democracy, in a word, is meant the existence of an aristocracy, expanded to a comprehensive aristocracy" (Strauss L., 2000: 311-312). Proceeding from this understanding of democracy, the relationship between politics and education is revealed in a different perspective: education does not fulfill a political order, but creates a condition for the possibility of politics as such.

The situation is complicated by the fact that any power is peculiar to be invisible, implicit. After all, "coercion does not lead directly to conviction" (Strauss L., 2012: 13). The result of effective "symbolic violence" is the naturalization of power, the transformation of subjects of social ties into its personification. The implicit, unreflexive dominance of the abstract-general in the pedagogical process gives the educational environment the bizarre forms in which the formation and production of the individual become identical. As a consequence, politics, the state, and the existing social order are given the opportunity to solve their specific problems through education. To solve the specific problems with the help of a person ultimately. From the point of J. Dewey's view, education should not have a goal outside of itself, it is the same as "growth" (Dewey J., 2000: 54). In a democratic society, as the thinker believed, the goal of education should be to create the possibility of continuing human growth. This is possible on the basis of equality, outside of which education begins to obey the goals imposed on him from outside. "The latter always arise if inequality persists in a society. In this case, the goals of some social groups are determined by external dictates, and are not appeared in the course of free development of experience, they serve as means for achieving other, supposedly higher, but alien goals" (Dewey J., 2000: 200). Thus, the essence of education as a common cause is realized in conditions of democratic equality. Not only politics is possible with the assistance of education, but the latter is consistent with the logic of human development, i.e. it has no goal outside of itself, only in the regime of politics, in the mode of open possibility of a dispute about the general.

\section{Conclusions}

Education is nothing more than a common affair; it is a "republic" in which the personality of all its subjects develops: both teachers and students. This is a joint venture, since 
the formation of personality is a social event. Otherwise, the formation of personality occurs as a gift of the personal origin from one person to another. But in order to give something as a gift, it is necessary to have it. And since the personality is not a gift and it does not belong to an isolated self, so it is necessary to keep up to date the personal principle. The existence of the personality is created between the notions "I" and "you", and not "inside" the opposing and isolated "ego". Without "you" there is not and cannot be "I". If the essential connection between people is torn apart for various reasons, only "ego" remains. But the totality of "ego" cannot create a universal symbolic order, they interact as parts that try to preserve their "individuality" at any cost. The lack of experience of participation in the universal excludes them from a common cause in which they perceive the threat of their own exclusivity. In general, a person appears not just private, which is opposed to the common. In general, a person appears as special, i.e. one that embodies, bears within itself the universal. At this point, politics and education are getting closer. They are the practice of creating and sharing a common, taking an active participation in it.

\section{References}

Althusser, L. (2011). Ideologiya i ideologicheskie apparaty gosudarstva (zametki dlya issledovaniya) [Ideology and ideological apparatus of the state (notes for research)]. Neprikosnovennyi zapas, 3, 14-58. (S. Ryndin, Trans.). Moscow: Novoe literaturnoe obozrenie. [in Russian].

Arendt, H. (1961). Between Past and Future. New York: Viking. [in English].

Aristotle (1983). Sochineniya: v 4 t. [Compositions: In 4 volumes]. Vol. 4. (A. Dovatur, Trans.). Moscow: Mysl. [in Russian].

Biesta, G. (2014) The Beautiful Risk of Education. Boulder: Paradigm Publishers. [in English]. Bourdieu, P. (1997). Sistema obrazovaniya i sistema myshleniya [The education system and the system of thinking]. Vysshee obrazovanie v Rossii, 2, 119-26. [in Russian].

Bourdieu, P., Kachanov, Yu., Pento, L., Shmatko, N. (2001). Sotsioanaliz Pierre Bourdieu. Almanakh Rossiisko-frantsuzskogo tsentra sotsiologii $i$ filosofii Instituta sotsiologii Rossiiskoi Akademii nauk [Sociological analysis of Pierre Bourdieu. Almanac of the Russian-French Center for Sociology and Philosophy of the Institute of Sociology of the Russian Academy of Sciences]. N. Shmatko (Ed.). Moscow: Institut eksperimentalnoi sotsiologii, Saint Petersburg: Aleteiya. [in Russian].

Bourdieu, P., Passeron, J.-Cl. (2007). Vosproizvodstvo: elementy teorii sistemy obrazovaniya [Reproduction: elements of the theory of the education system]. (N. Shmatko, Trans.). Moscow: Prosveshchenie. [in Russian].

Dewey, J. (2000). Demokratiya i obrazovanie [Democracy and Education]. (Yu. Turchaninov, N. Mikhailov, Trans.). Moscow: Pedagogika-Press. [in Russian].

Foucault, M. (1996). Volya k istine: po tu storonu znaniya, vlasti i seksualnosti. Raboty raznykh let [Will to truth: beyond knowledge, power and sexuality. Works of different years]. (S. Tabachnikova, ed. A. Puzyrey, Trans.). Moscow: Kastal. [in Russian].

Foucault, M. (1998). Istoriya seksualnosti III: Zabota o sebe [The history of sexuality III: Taking care of yourself]. (T. Titova, O. Khoma, Trans.). Kyiv: Dukh i litera, Moscow: Refl-buk. [in Russian].

Foucault, M. (2006). Drugie prostranstva [Other Spaces]. Intellektualy i vlast: izbrannye politicheskie statji, vystupleniya i intervyu, 3, 191-204. (B. Skuratov, Trans.). [in Russian]. 
Kharkhordin, O. (2009). Res publica: vozrozhdenie interesa [Res publica: revival of interest]. Chto takoe respublikanskaya traditsiya, 3, 7-22. [in Russian].

Kurennoy, V. (2008) Gosudarstvo kak mekhanizm depolitizatsii [State as a mechanism of depoliticization]. Nauchnye tetradi Instituta Vostochnoi Evropy, 3, 86-101. [in Russian].

Mouffe, Ch. (2005). On the Political (Thinking in Action). London, New York: Routledge. [in English].

Pakhlovska, O. (2003). Ukrainska kultura u vymiri "post»: postkomunizm, postmodernizm, post vandalism [Ukrainian culture in the measurement "post": postcommunism, postmodernism, post vandalism]. Suchasnist, 10, 70-85. [in Ukrainian].

Pantin, I. (2008). Politiko-filosofskii ezhegodnik [Political and philosophical yearbook]. I. Pantin (Ed.). Issue 1, 88-102. Moscow: IFRAN. [in Russian].

Ranciere, J. (2006). Na krayu politicheskogo [At the edge of the political]. (B. Skuratov, Trans.). Moscow: Praksis. [in Russian].

Strauss, L. (2000). Chto takoe klassicheskoe obrazovanie? [What is a classical education?]. Vvedenie v politicheskuyu filosofiyu. L. Strauss. Trans. M. Fetisov (Ed.). Moscow: Logos, Praxis, 310-316. [in Russian].

Strauss, L. (2012). Presledovanie i iskusstvo pisma [Pursuit and the art of writing]. Sotsiologicheskoe obozrenie, 3, 12-25. (B. Skuratov, Trans.). [in Russian].

Szkudlarek, T. (Eds.). (2013). Education and the political: New theoretical articulations. Rotterdam, the Netherlands: Sense. [in English]. 